\title{
ESSAYS
}

\section{The Fifth Amendment and Custodial Questioning: A Response to "Reconsidering Miranda"}

Stephen J. Markman†

In an article entitled "Reconsidering Miranda," Professor Stephen Schulhofer undertakes to examine a number of basic issues in the law of pretrial interrogation. While ostensibly cast as a critique of a report to the Attorney General on this subject that was prepared under my direction, ${ }^{2}$ Schulhofer's article is largely devoted to attacking the Supreme Court's jurisprudence relating to custodial questioning and traditional understandings of the fifth amendment.

Regrettably, Schulhofer's article fails to shed new light on these important issues. Its arguments and analyses consistently reflect basic misapprehensions concerning relevant legal, historical, and factual matters.

Sections I and II of the article are primarily devoted to arguing that the Supreme Court and my office's report are wrong in viewing the fifth amendment in its application to custodial questioning as a prohibition of coercive interrogation, and to defending the Miranda decision's assumption-now rejected by the Supreme Court itself - that unconstitutional compulsion invariably occurs in custodial questioning unless an elaborate set of prophylactic procedures is observed. Section III then undertakes a more specific defense of one of the Miranda warnings. In section IV, Schulhofer

† Assistant Attorney General for Legal Policy, United States Department of Justice. B.A., Duke University; J.D., University of Cincinnati College of Law. The views expressed in this article are those of the author alone and do not necessarily reflect those of the Department of Justice.

${ }^{1}$ Stephen J. Schulhofer, Reconsidering Miranda, 54 U. Chi. L. Rev. 435 (1987). All parenthetical page references are to Schulhofer's article.

${ }^{2}$ Office of Legal Policy, Report on the Law of Pre-Trial Interrogation (Feb. 12, 1986) ("Report on Pre-Trial Interrogation"). 
attempts to explain away empirical evidence concerning the $\mathrm{Mi}$ randa decision's harm to law enforcement. The article ends with a call for imposing more stringent restrictions on criminal investigation than the Miranda rules. These points will be discussed in turn. ${ }^{3}$

\section{The Fifth Amendment}

Schulhofer initially argues that (1) "compulsion" within the meaning of the fifth amendment is not limited to the threat of legal sanctions and that (2) pressures on a suspect that fall short of "breaking his will" may constitute "compulsion" in the constitutional sense. These propositions are obviously correct, and my office's report is fully consistent with them.

A significant point of difference appears, however, in Schulhofer's contention that any form of pressure that is intended to elicit responses from a criminal suspect is proscribed "compulsion" under the fifth amendment. Schulhofer admits that this proposition is clearly rejected by the Supreme Court in its current decisions concerning custodial questioning. ${ }^{4} \mathrm{He}$ essentially argues, however, that such decisions should be overruled in light of other Supreme Court decisions concerning adverse comment on the defendant's silence at trial and threatened dismissal from public service, and the principle that threats of criminal punishment (incarceration or fines) may constitute compulsion in violation of the fifth amendment. Starting from the fact that these particular pressures have been considered "compelling" in certain circumstances, Schulhofer leaps to the conclusion that there is a general principle that any pressure "imposed for the purpose of discouraging the silence of a criminal suspect constitutes prohibited compulsion"( $p$. 445).

"Discouraging silence," however, is precisely the purpose of summoning a targeted witness before a grand jury and asking him questions on pain of contempt for refusing to answer. The same purpose is served by summoning a suspected accomplice to testify at trial and questioning him concerning his involvement in the defendant's criminal acts, again under threat of contempt for refus-

s In light of the space limit imposed on this essay, its discussion is necessarily limited to the most general points raised in Schulhofer's article. Failure to address more specific criticisms of my office's report or other matters that appear in the article should accordingly not be understood as reflecting a view that these other arguments or assertions have any merit.

See, e.g., Oregon v. Elstad, 470 U.S. 298 (1985). 
ing to respond. In general, the Supreme Court has held, even the prospect of criminal sanctions does not violate the fifth amendment, so long as a person is not "required to answer over his valid claim of the [fifth amendment] privilege."

Schulhofer's confusion concerning the general understanding of the fifth amendment's prohibition of compulsion is strikingly illustrated by his assertion that "[a]t trial, any penalty imposed on a witness for refusal to testify constitutes 'compulsion' and is impermissible if there is potential self-incrimination . . . [but] . . once the witness freely chooses to testify, the state can subject the witness to 'compulsion'" (p. 444). In fact, the provision of a "free choice" whether to testify at trial is limited to the defendant, whose option of refusing to take the stand in criminal trials results from late-nineteenth-century statutory developments that abrogated the testimonial incapacity of defendants. In both trial and pretrial proceedings, other witnesses, including those who are themselves suspected of criminal acts, have no right to prevent questioning and may be presented with very substantial incentives to respond. ${ }^{6}$

Thus, the Supreme Court's rejection of Schulhofer's view is equally clear in cases relating to custodial questioning and in other contexts. There is, moreover, an abundance of direct evidence concerning the historical understanding of the right against compelled

- Minnesota v. Murphy, 465 U.S. $420,427-29$ (1984). While a witness summoned to testify at trial or before a grand jury may claim the fifth amendment right instead of responding to potentially incriminating questions without penalty, the burden is on him to do so. His answers to such questions, though given under the pressure of a perceived risk of contempt sanctions for refusing to respond, are not compelled in the fifth amendment sense. See id. at $427-29,431,436-37$.

It should be noted further that even when a suspect does claim the fifth amendment right, the applicable rule under Miranda-that all questioning must cease if the suspect indicates in any manner that he is unwilling to talk-is more extreme than that applied in other fifth amendment contexts. In other contexts a suspect or witness cannot be punished for validly asserting the fifth amendment right, but he has no right to prevent further questioning. See generally Namet v. United States, 373 U.S. 179 (1963); Report on Pre-Trial Interrogation at 32, 50 (cited in note 2).

The specific cases cited by Schulhofer in support of his zero-pressure theory-Griffin $v$. California and Lefkowitz $v$. Cunningham-actually relate to situations in which a person is subjected to a "penalty" for failing to waive the fifth amendment right or is presented with a specific threat that he will be punished for exercising the right. See Griffin, 380 U.S. 609, 614 (1965); Murphy, 465 U.S. at 434-39 (explaining ambit of Lefkowitz and related decisions). While the expansive notion of penalty or punishment reflected in these decisions is not beyond criticism, see generally Report on Pre-Trial Interrogation at 30-32 (cited in note 2); Lefkowitz, 431 U.S. 801, 810-11 (1977) (Stevens, dissenting), it is clear that they do not support the proposition that no effort may be made to discourage silence by a suspect.

${ }^{\circ}$ See Murphy, 465 U.S. 420. 
self-incrimination in the context of custodial interrogation. As Schulhofer admits, the historical counterpart in the common law system of the current practice of police interrogation was the questioning of suspects in custody by justices of the peace or other magistrates (the common law "preliminary examination"). Recognition of the suspect's right against compelled self-incrimination was reflected in a traditional rule against questioning him under oath at the preliminary examination, and torture or physical abuse of the suspect was, of course, also prohibited. The proceeding was not restrained, however, by attenuated or fictitious notions of compulsion. The magistrate's questioning could have an aggressive character, and the normal psychological pressures or incentives presented by custodial questioning were not regarded as circumstances that impermissibly "compelled" the suspect to respond. There was no right on the part of the suspect to refuse to be questioned and no rule that a suspect had to be advised that he was not required to respond. Any statements or admissions made by the suspect at the examination-as well as any refusal on his part to answer questions-could be disclosed at trial. ${ }^{7}$

Schulhofer elsewhere alleges that "it seems clear that the [fifth amendment] privilege was intended to bar pretrial examination by magistrates" (p. 438), ${ }^{8}$ which may explain why he ignores

' See, e.g., Edmund Morgan, The Privilege Against Self-Incrimination, 34 Minn. L. Rev. 1, 14, 18, 22-23 (1949); Lewis Mayers, Shall We Amend the Fifth Amendment? 10, 16, 175, 188, 223-24 (1959); Leonard W. Levy, The Origins of the Fifth Amendment 325, 375 (1968); Report on Pre-Trial Interrogation at 1-7 (cited in note 2).

As the cited sources show, the use of torture and other inquisitorial practices was proscribed by the establishment of the right against compelled self-incrimination in th: midseventeenth century, but the features of the preliminary examination described in the accompanying text persisted thereafter and were considered unproblematic at the time of the Constitution.

Contrary to Schulhofer's assumption, preliminary examinations by magistrates were not carried out "under formal process," if "formal process" is meant to refer to questioning under oath or other arrangements that would entail a legal obligation to respond. The right against compelled self-incrimination applied in all types of proceedings, including those-such as the preliminary examination-in which there was no legal obligation to answer. While the right was generally applicable, regardless of the presence or absence of an oath, its substantive interpretation was flatly inconsistent with Schulhofer's fictitiously broad concept of compulsion. It was not understood to mean that a suspect could prevent questioning from taking place, or that he had a right to be advised by the authorities that he was not required to respond. See, e.g., Levy, The Origins of the Fifth Amendment at 375, 406; Report on Pre-Trial Interrogation at 6-7 (cited in note 2).

B Schulhofer cites in support to Lewis Mayers, The Federal Witness' Privilege Against Self-Incrimination, 4 Amer. J. Legal Hist. 107, 114 n.20 (1960). However, the point of the cited footnote was that the fifth amendment right may have been directed primarily against oppressive interrogation in pretrial contexts, and particularly against executive inquisitions. See id. at 113-14 \& nn. 19-20. Professor Mayers was, of course, aware that the elimination of 
the existing understanding of the right against compelled self-incrimination in the context of such examinations at the time of the Constitution. ${ }^{\ominus}$ However, Schulhofer's underlying assumption concerning the purpose of the amendment is groundless. The notion that the fifth amendment was meant to abolish preliminary examinations of suspects would have startled the framers and ratifiers of the amendment, considering that such examinations were a basic feature of criminal procedure in their time, had been for over 200 years beforehand, and remained so until the mid-nineteenth century, at which point they were generally replaced by police interrogation. ${ }^{10}$ At the federal level, examinations of this type persisted until at least the final decade of the nineteenth century. ${ }^{11}$

\section{InHEREnT Coerciveness}

Having failed to justify nullifying the fifth amendment's requirement of "compulsion" on the basis of precedent or history, Schulhofer then turns to an attempted justification of the Miranda decision's central premise-the notion that custodial questioning always involves unconstitutional compulsion unless an elaborate set of prophylactic procedures is observed. The plausibility of this assumption may be assessed by considering, for example, the case of the defiant criminal who reviles his questioners and boasts to them of his crimes; the case of the calculating criminal who eagerly enters into conversations with the police as a means of advancing a fabricated defense or finding out how much they know; the case of the contrite criminal who freely gives a full confession as soon as the police ask him what happened, as a means of relieving his burden of guilt; and the case of the factually innocent suspect who indignantly denies his guilt and welcomes the custodial interview as an opportunity to respond to the false charges against him. The

the common law procedure of preliminary examinations was a nineteenth-century development, and observed explicitly in his book on the fifth amendment that "those who in this country framed the constitutional provisions against self-incrimination made no attempt to change that procedure." Mayers, Shall We Amend the Fifth Amendment? at 176 (cited in note 7). Schulhofer's other citation is to Yale Kamisar, Police Interrogation and Confessions 48-55 (1980), which is primarily concerned with other fifth amendment issues and postConstitution developments, and does not allege that the fifth amendment was intended to abolish preliminary examinations, much less that this point is "clear."

- See generally Levy, The Origins of the Fifth Amendment at 405-32 (cited in note 7) (fifth amendment right derived from existing right recognized in the United States and applicable in all types of proceedings, including preliminary examinations).

${ }^{10}$ See, e.g., Mayers, Shall We Amend the Fifth Amendment? at 16, 175-76, 187-88, 223-24 (cited in note 7).

11 See Wilson v. United States, 162 U.S. 613 (1896). 
Miranda decision's assumption concerning the "inherent coerciveness" of custodial questioning presupposes that such suspects are invariably compelled by the government to be witnesses against themselves in violation of the fifth amendment unless the Miranda procedures are fully observed. This untenable assumption has long since been abandoned by the Supreme Court. ${ }^{12}$

Recognizing the vulnerability of the "inherent coerciveness" assumption on which the Miranda decision actually predicated its system of rules, Schulhofer elsewhere advances the quite different rationale that the Court may validly create an "irrebuttable presumption," of constitutional stature, that compulsion always occurs in custodial questioning-a presumption that applies even when it is clear that no compulsion actually took place (pp. 44849). Stripped of legalese, this amounts to the contention that the Court may validly pretend that compulsion occurred-though it did not-and require both federal and state courts to exclude evidence on the basis of that pretense as a matter of federal constitutional law. As a statement about institutional authority, it assumes that the Court may create a new "constitutional" rule requiring the exclusion of evidence that was admittedly obtained without compulsion, and therefore in conformity with our written Constitution.

It is a long road from the Constitution itself to such an asserted judicial power of constitutional amendment, and Schulhofer does not succeed in travelling it. Supposed "irrebuttable presumption" decisions by the Supreme Court actually reflect ordinary interpretation of constitutional standards in most instances, ${ }^{13}$ and the Court has consistently characterized the "irrebuttable presumption of compulsion" reflected in the practical operation or the Miranda rules as a nonconstitutional prophylactic measure. When Justice Stevens advanced the same "irrebuttable presumption" theory as Schulhofer as a basis for according constitutional status to the Miranda rules in Oregon v. Elstad, ${ }^{14}$ the Court had no difficulty rejecting it as inconsistent with the Miranda decision itself and with various other decisions. ${ }^{15}$

Finally, Schulhofer's contention that "enormous adjudicatory burdens" (p. 450) would result if the courts did not augment the

12 See Michigan v. Tucker, 417 U.S. 433, 443-46 (1974).

${ }^{13}$ See generally Joseph Grano, Prophylactic Rules in Criminal Procedure: A Question of Article III Legitimacy, 80 Nw. U. L. Rev. 100 (1985).

14 470 U.S. 298, 364-72 (1985) (dissent).

${ }^{15}$ See id. at $306-07$ n.1. 
written Constitution with broader "constitutional" restrictions on the government based on irrebuttable presumptions is particularly unpersuasive as support for Miranda's innovations. Miranda has not eliminated litigation under the voluntariness standard, since defendants who have received the full Miranda treatment remain free to claim that they were nevertheless coerced; and they do so frequently. Moreover, Miranda's requirements have given rise to an enormous volume of litigation of a wholly novel character. This includes litigation relating to the existence of a "custodial" situation requiring warnings prior to questioning; the delivery and formulation of the warnings; the adequacy of a suspect's waiver; compliance with the rules against questioning a suspect who has expressed an unwillingness to talk or who has requested counsel; compliance with the rule that a suspect's silence following the receipt of Miranda warnings must be concealed from the jury at trial; and various other matters. Given Miranda's status as a major source of litigable issues in its own right, there is no reason to believe that it has had any overall effect of reducing the volume or complexity of litigation relating to the admissibility of defendants' statements.

\section{The Miranda Rules}

In Section III, Schulhofer turns to Miranda's specific requirements. The defense of these requirements in this section is surprisingly selective. As indicated above, the Miranda decision created a variety of novel restrictions on police investigation, including a substantive right to counsel in connection with custodial questioning, the delivery of four specific warnings to the suspect before questioning, the requirement that the suspect give a "knowing and intelligent waiver" of the rights set out in the warnings, and a rule that all questioning must cease immediately if the suspect indicates in any manner that he is unwilling to talk or asks for a lawyer.

Schulhofer makes no effort to show that all these extra-constitutional restrictions are essential to dispelling the alleged "inherent coerciveness" of custodial questioning, but limits his specific defense to the first Miranda warning- "you have a right to remain silent"-arguing that it is "double-talk" to say that a suspect was not subjected to unconstitutional compulsion if he responded to official inquiry while under the misapprehension that he was obligated to do so (p. 455).

However, the government does not violate the fifth amendment simply by questioning and obtaining answers from a suspect 
who may believe mistakenly that he is required to respond. This point is equally clear under the Supreme Court's fifth amendment decisions and under the original understanding of the fifth amendment right. ${ }^{16}$ Schulhofer's argument is particularly peculiar in its suggestion that there is an inconsistency between this settled principle and the observation of my office's report that a "right to remain silent" warning "does . . . have some pragmatic value in rebutting claims of coercion."17 As a matter of common sense, it is more difficult for a defendant to establish that he was forced to confess if he was told explicitly before questioning that he did not have to say anything. This obviously does not imply that the absence of such a warning amounts per se to unconstitutional compulsion. Nor is there anything confusing in telling a suspect that he does not have to respond, but that his failure to do so may make it harder for people to believe a defense he offers later on.

\section{Empirical Evidence of Miranda's Harm to Law ENFORCEMENT}

In section IV of his article, Schulhofer argues that the $\mathrm{Mi}$ randa rules have had little adverse effect on law enforcement and that any negative impact of the Miranda decision was evanescent. This contention, in my opinion, is false, and Schulhofer does not attempt to show-much less succeed in showing-that a single study supports it. As my office's report noted, empirical studies commonly cited by defenders of Miranda on this point have involved gross methodological errors or affirmative findings that the police were not yet complying with Miranda in the jurisdictions examined at the time of the studies. ${ }^{18}$

Conversely, a number of studies-including studies in Philadelphia, New York County, and Pittsburgh-found immediate, dramatic reductions in statements and admissions obtained in custodial questioning following the implementation of the Miranda rules. For example, the Philadelphia study found that the number of suspects who refused to make statements to police detectives increased from 32 percent before Miranda to 59 percent after $M i$ randa. The New York study found that the percentage of nonhomicide felony cases presented to grand juries that involved incriminating admissions fell from 49 percent before Miranda to 15

16 See, e.g., Murphy, 465 U.S. at 420; Levy, The Origins of the Fifth Amendment at 375 (cited in note 7) (same historical understanding).

${ }^{17}$ Report on Pre-Trial Interrogation at 105 (cited in note 2).

1s See id. at 58-59 n.90 (cited in note 2). 
percent after Miranda. The Pittsburgh study found that the percentage of suspects who confessed fell from 48.5 percent before $M i$ randa to 32.3 percent after Miranda, with much larger reductions in some crime categories, including a reduction from about 60 percent to about 30 percent in the homicide and robbery categories. The findings in Philadelphia and Pittsburgh would actually understate the full effect of the Miranda system, since the police in these jurisdictions were already complying with some of the $\mathrm{Mi}$ randa rules in the relevant pre-Miranda period as a result of related judicial decisions that occurred shortly before Miranda.

Schulhofer's efforts to explain away these findings are, to say the least, unconvincing. The reports of the Philadelphia and New York studies do not support his assertion that "[t]he data for preMiranda and post-Miranda periods were not compiled by comparable methods" (p. 457), ${ }^{18}$ and he fails to produce any other evidence that supports this contention. In noting that the Pittsburgh study did not find a significant change in conviction rates, he relegates to a footnote the authors' explanation that cases that could not be prosecuted at all because the police were barred from obtaining evidence by the Miranda rules would not be reflected in conviction rate figures (p. 458 n.59). ${ }^{20} \mathrm{He}$ also ignores their expla-

19 See Controlling Crime Through More Effective Law Enforcement: Hearings before the Subcomm. on Criminal Laws and Procedures of the Senate Comm. on the Judiciary, 90th Cong., 1st Sess. 200-01, 204-06 (1967) (Philadelphia study); id. at 1120, 1123 (New York study).

The report of the Philadelphia study indicated that its statistics, both before and after Miranda, covered detective division cases in which a suspect refused to make a statement following the receipt of warnings. See id. at 200, 205-06. Aside from the implementation of Miranda, there is no evidence that any other change in police practices occurred at the time that would account for the increased frequency of refusals to talk.

The report of the New York study indicated that its statistics, both before and after Miranda, gave the proportion of non-homicide felony cases that reached the grand jury stage in which an incriminating admission was presented to the grand jury. If the postMiranda figure of 15 percent reflected a failure to present admissions obtained in pre-Miranda interrogations because of the partial retroactivity of Miranda, see Johnson v. New Jersey, 384 U.S. 719 (1966), then the findings of this study would only illustrate a shortterm effect of the Miranda decision. However, the report of the study assumed that the proportion of cases in which the defendant had confessed was the same as the proportion of cases in which confessions were presented to grand juries. See Hearings at 1120 ("Only 15\% confessed in the six months after the Miranda ruling and $49 \%$ confessed before."). Barring misrepresentation by the report, this implies that pre-Miranda confessions were presented to grand juries regardless of their inadmissibility at trial, or that the number of cases affected by retroactivity was not statistically significant. Presenting to grand juries evidence that is inadmissible at trial on fifth amendment grounds or other grounds is consistent with the Supreme Court's decisions both before and after Miranda. See United States v. Calandra, 414 U.S. 338, 344-46 (1974); Lawn v. United States, 355 U.S. 339, 349-50 (1958).

.20 "Conviction rate" refers to the percentage of prosecutions in which a conviction is 
nation that the study's conviction rate figures related to a broad area encompassing police agencies that may not have been complying with the Miranda rules at the time of the study. ${ }^{21}$ Schulhofer's citation of favorable remarks concerning Miranda by the authors of two of these studies shows nothing but their current ideological affinities for the Miranda decision. The damage to law enforcement disclosed by their findings speaks for itself.

Finally, Schulhofer's assertion that this damage has been alleviated through the adjustment of police practices to Miranda's requirements is not only unsupported by any empirical evidence but is also inherently illogical. The main cost of the Miranda rules is the loss of statements that are never obtained to begin with because compliance with Miranda prevents the police from questioning a suspect or inhibits him from responding. ${ }^{22}$ More consistent compliance by the police can only increase this cost.

The last step in section IV of Schulhofer's article is an effort to dismiss some particular cases that were described in an appendix to my office's report as examples of damage to the criminal justice system that can result from the application of the Miranda exclusionary rule. As the report noted, in one of these (the Suarez case), a man who slaughtered his wife and five children was freed because the Miranda rules had not been observed in his pre-Miranda interrogation. While Schulhofer asserts that this case somehow illustrates the danger of any "destabilizing changes" in case law (p. 458), its more obvious "lesson" is the danger of innovative judicial decisions that require the exclusion of reliable evidence obtained in conformity with the Constitution.

The other three cases are recent. In each of the cases, evidence was excluded on the basis of a judicial determination that the police had not complied with Miranda. In each of the cases, it was

obtained. If 100 cases can be prosecuted and convictions result in 80 , the conviction rate is 80 percent. If only 10 cases can be prosecuted because evidence is unavailable in the other 90 , and conviction results in 8 of the prosecuted cases, the conviction rate is still 80 percent. Moreover, conviction rates take no account of cases in which a defendant secures a plea to a lesser offense or to fewer counts because the unavailability of evidence has weakened the government's case, and take no account of the need to commit additional resources in investigating cases that might have been made easily if the suspect had made a statement or answered questions. Conviction rates accordingly do not provide a reliable measure of the effect on law enforcement of the Miranda rules or other rules restricting the collection of evidence.

${ }^{21}$ See Richard M. Seeburger and R. Stanton Wettick, Miranda in Pittsburgh: A Statistical Study, 29 U. Pitt. L. Rev. 1, 24 (1967).

${ }^{22}$ See id. at 13 (over 40 percent of suspects in study sample could not be questioned because of Miranda rules). 
clear that the evidence would not have been subject to exclusion had its admissibility been decided under the constitutional standard of actual compulsion, rather than the prophylactic Miranda standards. The effects of the exclusion were various: freeing a killer (Gaspard), squandering the system's resources in retrying a triplemurderer whose guilt was not in doubt (Braeseke), and enabling a murderer to exact a reduced sentence as the price for a guilty plea following multiple trials and appeals ( $E$ dwards). While Schulhofer asserts that reliance on the constitutional standard would aggravate the problems illustrated by these cases, their obvious "moral" is, rather, the unsoundness of continuing rules that permit the exclusion of statements that are clearly voluntary and reliable.

\section{Conclusion}

In summarizing, it may be helpful to set out in positive terms an accurate statement concerning the main issues addressed by Schulhofer. The fifth amendment was not meant to bar noncoercive questioning of suspects in custody, has not traditionally been so understood, and is not so understood today. The various restrictions imposed by the Miranda rules were unheard of prior to the innovative decisions of the 1960s and have no basis in the Constitution. The Supreme Court is clearly correct in its present view that the Miranda rules are only "suggested safeguards" that are not required by the Constitution. ${ }^{23}$

The costs of the Miranda system to the public's interest in effective law enforcement are great, and no progress in alleviating these costs can be expected so long as the Miranda decision continues to hold sway. In this regard, Justice White's words in his Miranda dissent were prophetic:

In some unknown number of cases the Court's rule will return a killer, a rapist or other criminal to the streets and to the environment which produced him, to repeat his crime whenever it pleases him. As a consequence, there will not be a gain, but a loss, in human dignity. . . . There is, of course, a saving factor: the next victims are uncertain, unnamed and unrepresented in this case. ${ }^{24}$

${ }^{23}$ See, e.g., Tucker, 417 U.S. at 443-46 (1974); New York v. Quarles, 467 U.S. 649 (1984); Connecticut v. Barrett, 107 S.Ct. 828, 832 (1987).

${ }_{24}$ Miranda v. Arizona, 384 U.S. 436, 505 (1966). More extensive discussion and analysis of the Miranda rules' inadequacy as safeguards against interrogation abuses appear in my office's report. See Report on Pre-Trial Interrogation at 43-45, 94-95 (cited in note 2). 
No discussion of the Miranda rules would be complete without some mention of their shortcomings in relation to their avowed purpose of protecting suspects against abusive interrogation. As Justice Harlan observed in his Miranda dissent: "The new rules are not designed to guard against police brutality or other unmistakably banned forms of coercion. Those who use third-degree tactics and deny them in court are equally able and destined to lie as skillfully about warnings and waivers." 25 Schulhofer is obviously aware of the desirability of better safeguards, but seems oblivious to the fact that it is the Miranda decision itself that has effectively prevented their adoption. The early 1960s were characterized by intense interest in such possibilities as electronic recording of interrogations and other constructive reforms that would provide suspects with far more effective protection against overreaching than the Miranda rules without comparable costs to the investigative process.

The imposition by judicial fiat in Miranda of a detailed nationwide procedural system for custodial interrogations simply cut off this development. ${ }^{26}$ The experience of the ensuing twenty years shows clearly that courts, legislators, and administrators will not impose additional restrictions on police questioning so long as the Miranda rules continue to exact heavy costs on the public's interest in protection from crime. Conversely, breaking the stranglehold of the Miranda rules on the investigative process would open the way for a renewal of legislative and administrative involvement in this area, restoring "the initiative in criminal law reform to those forums where it truly belongs." Defenses aimed at locking in the Miranda regime are accordingly as inimical to the effective protection of constitutional rights as they are to the effective prosecution of crime.

25384 U.S. at $542-43$.

${ }^{26}$ See American Law Institute, Model Code of Pre-Arraignment Procedure § 130.4, commentary at 341-42 (1975); Report on Pre-Trial Interrogation at 36-38, 54-57, 96 (cited in note 2).

${ }^{27}$ Miranda, 384 U.S. at 524 (Harlan, dissenting). 